\title{
Characterisation of materials and techniques in first archaeological findings of Nasca wall paintings
}

Nathalie Boucherie ${ }^{1 *} \mathbb{D}$, Witold Nowik ${ }^{2,3}$ and Nathalie Pingaud ${ }^{2,4}$

\begin{abstract}
The pre-Colombian wall paintings in Peru were already known from north and central coast sites, but little information exists on the southern coast corresponding to the Nasca region. The recent excavations on Cahuachi site provided fragments of plaster with paint layers found near Great Pyramid, corresponding to phases III and IV of the construction of the site, and dating back to the Early Intermediate Period (from 200 BC to 350 AD). A series of fragments from three locations from these two respective periods were transferred directly from the excavation to the laboratory and analyzed. A panel of observation and analysis methods was applied in order to describe the stratigraphy and materials used for these paintings, with special attention to the paint layer. The stratigraphy was observed by optical and electron microscopies and X-ray fluorescence, Raman and infrared spectroscopies were employed for elemental and molecular characterization of the plaster and paintings. The obtained results show the large presence in painting layers of iron oxides and copper based pigments, as well as calcium sulfate, siliceous clay materials and graphite. Although most of these pigments could be provided by local deposits, the detection of graphite is probably linked to the use of charcoal. The variety of painting materials between phases III and IV are related to the palette of colours and pigments. The colours for phase III seem limited to the red and yellow ochre pigments, and unidentified black and gypsum white. During phase IV, additional pigments were identified such as: paratacamite, malachite and chrysocolla for greens, hematite for purple, charcoal and siliceous white, which replaced gypsum white. The paintings were sometimes applied in several layers and occasionally separated by a white coating layer. The painting materials and techniques identified on Cahuachi site, and especially the differences between the phases observed, constitute a new insight into the knowledge of wall painting tradition in Southern Peru.
\end{abstract}

Keywords: Wall painting, Nasca, Characterization, Pigment, MEB-EDX, FTIR, Raman

\section{Introduction}

As well as rock painting [1-3], wall painting is an ancient tradition in the Andean area [4].

The oldest examples of mural painting were discovered on the north coast, where presumably the pictorial technique appeared in the Pre-Ceramic period. Mural painting was then developed during the Early Horizon through the Chavín style and continued in the following periods

\footnotetext{
*Correspondence: boucherienathalie33@gmail.com

${ }^{1}$ Bordeaux, France

Full list of author information is available at the end of the article
}

on the north and central coast: various studies have been carried out about mural remains which are numerous in this region [4-7]. In comparison, on the south coast the examples are much less numerous. However, beautiful friezes engraved and sometimes painted have recently been discovered in Animas Altas [8], an Early Horizon site.

The Nasca culture appeared on the south coast of Peru in the second century BC in the Rio Grande de Nasca basin (Fig. 1). During the first two centuries of its development, it coexisted with the Paracas culture that had

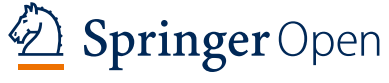

(c) The Author(s) 2021. This article is licensed under a Creative Commons Attribution 4.0 International License, which permits use, sharing adaptation, distribution and reproduction in any medium or format, as long as you give appropriate credit to the original author(s) and the source, provide a link to the Creative Commons licence, and indicate if changes were made. The images or other third party material in this article are included in the article's Creative Commons licence, unless indicated otherwise in a credit line to the material. If material is not included in the article's Creative Commons licence and your intended use is not permitted by statutory regulation or exceeds the permitted use, you will need to obtain permission directly from the copyright holder. To view a copy of this licence, visit http://creativeco mmons.org/licenses/by/4.0/. The Creative Commons Public Domain Dedication waiver (http://creativecommons.org/publicdomain/ zero/1.0/) applies to the data made available in this article, unless otherwise stated in a credit line to the data. 


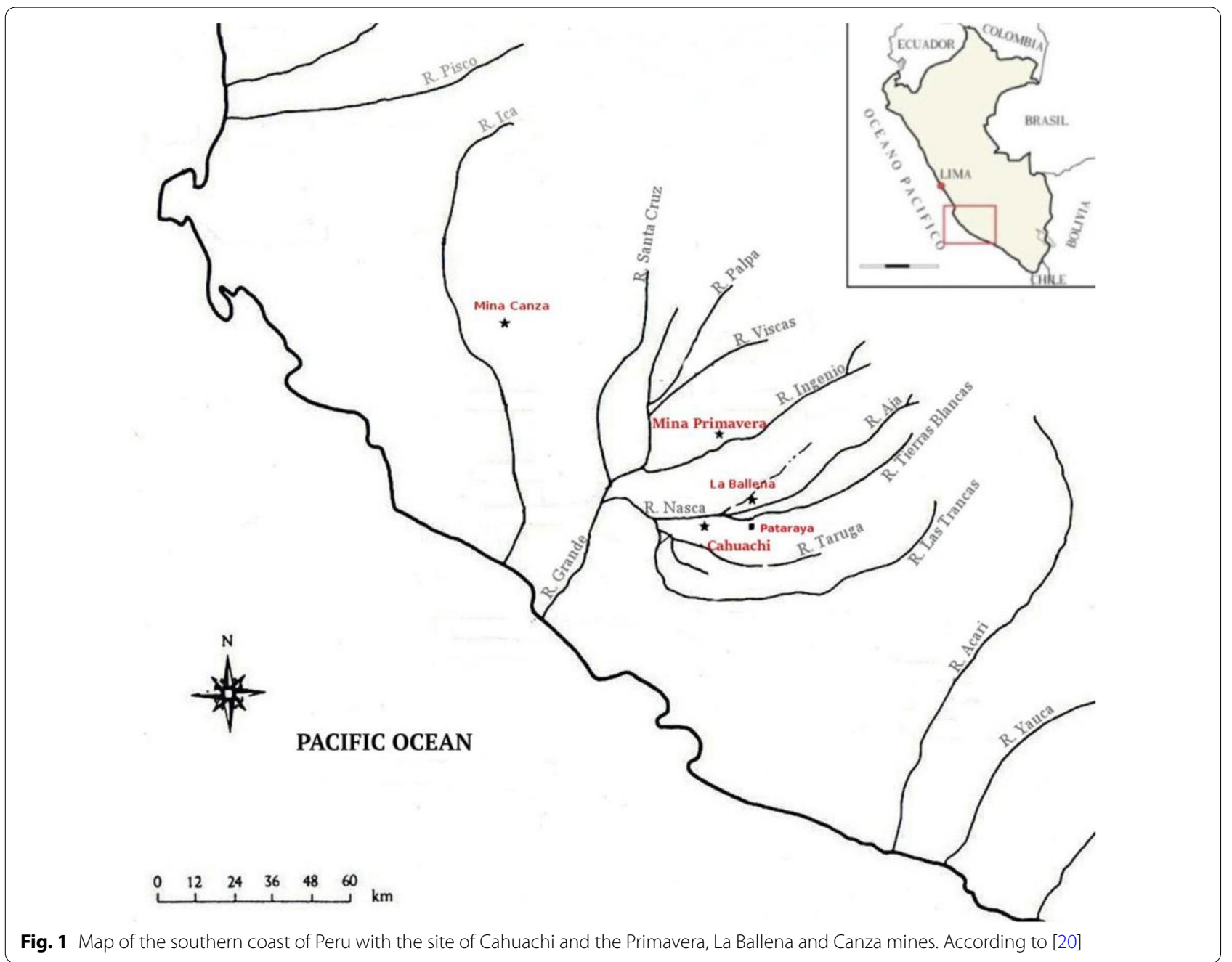

been established for 800 years BC in the valleys of Ica, Palpa and the Paracas peninsula.

The archaeological remains reflect social and political differences within the Nasca population [9-14]. The material culture and Nasca iconography suggest that there were specialists in several fields of activity in this society as for example, specialized ceramists $[15,16]$.

Polychromy is an important component in Nasca culture. Moreover, the Nasca seem to have been masters in the art of rich polychromy on objects of worship such as ceramics $[15,17]$ and textiles $[18,19]$. During the Early Nasca phase (-50, $400 \mathrm{AD})$, a major politico-ceremonial censer, Cahuachi was developed.

The Cahuachi site is located in the center of the Rio Grande basin, $42 \mathrm{~km}$ from the Pacific coast (Fig. 1). It was erected on the south bank of the Rio Nasca, in the middle of the valley and of natural mounds. The presence of water, rare in this arid region, made it a sacred place: a huaca. The site surface is estimated to be a vast
$24 \mathrm{~km}^{2}$. Until now, only part of the site has been excavated: the area where the most imposing buildings are concentrated.

The central sector of Cahuachi is made up of monumental ceremonial buildings, with the "Great Pyramid" and the "Great Temple", as well as other major structures. The monumental district extends east and west, linearly, with a high density of construction. The oldest buildings were constantly covered by new structures, until the abandonment of Cahuachi (around $400 \mathrm{AD}$ ). In general, the walls of the structures of the old platforms were dismantled and their surfaces were covered with embankments in order to reconstruct new platforms on the top.

We can thus identify four construction phases and a fifth phase during which the abandonment of the site was ritualized [21, 22]. The most monumental structures were erected during the phases $2(200 \mathrm{BC}$ to 0$)$ and $3(0$ to $250 \mathrm{AD}$ ): they consisted of several platforms two to three meters high, superimposed upon each other. Phase 3 coincides with the peak of the Cahuachi ceremonial 

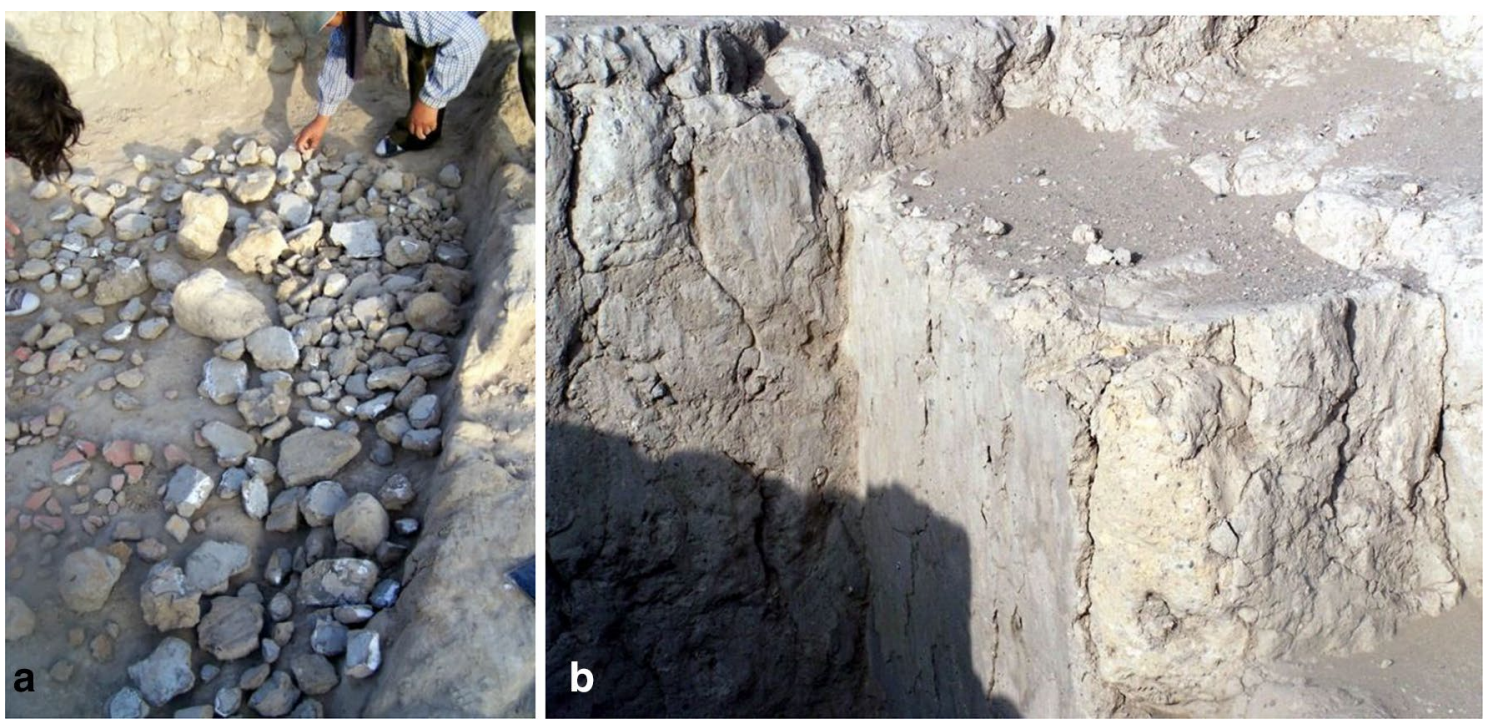

Fig. 2 a Fragments of wall paintings discovered in the lower part of the Great Pyramid. b A corner of the wall in sector Y2 Exp136 with the evident presence of a thick layer of plaster on the right wall and a thinner plaster showing adobes on the left. Photos: N. Boucherie

center activity. The oldest traces of wall paintings date back to the third phase of construction and then other painted decorations were applied during the fourth phase (250-400 AD) [21, 23]. During phase 4, the use of the Great Pyramid changed, and the interior space was divided into narrower passages [13, 22].

Archaeological excavations carried out in 2006 by Giuseppe Orefici revealed the existence of fragments of paintings on the walls of the great pyramid of Cahuachi. These are, up to now, the first examples of mural painting discovered on the site. They are one of the few murals discovered on the south coast.

Some fragments of wall paintings taken from the Cahuachi site were analyzed in the laboratory in order to characterize their materials and techniques [24]. This was the first analytical study on Cahuachi murals and on fragments directly transferred to the laboratory from an excavation site, which permitted to avoid any conservation treatment or museum collection storage.

\section{Archaeological context and sampling}

The central area of Cahuachi is made up of predominant monuments such as the Great Temple, the Orange Pyramid, the Temple of the Escalonado and the Great Pyramid. They are connected to each other and to several other minor temples by squares, enclosures, passageways and staircases.

The Great Pyramid, $30 \mathrm{~m}$ high, is the tallest building. Its stepped architectural form and the abundant vestiges of ritual objects seem to indicate that it was the focal point of religious activity. The first fragments of mural paintings were discovered in this building.

The remains of wall paintings split into small fragments of painted plaster were found at the base of the walls (Fig. 2a). As a result, this suggests that the coating had detached from the wall and fallen, further implying that the paintings are poorly conserved.

They are rare and too fragmentary to allow the original motifs to be reconstructed. In the upper part of the pyramid (phase 3), only fragments of yellow and red paint on white plaster were found, while in a lower area (phase $4)$, several colours were present: yellow, orange, red, green, white, black and purple. Black or white lines seem to emphasize the outlines of patterns. Some sections of the walls may have been painted in only one colour while others may have been decorated with polychrome patterns or scenes.

According to the first observations in situ, the preparation of the support and the pictorial technique seem to be relatively close to contemporary cultures of the central and northern coast: the surface of the adobe walls is covered with mud-based coatings [25]. This plaster is generally thick because it was used to even out the surface of the walls by filling in the hollows between the adobes (Fig. 2b).

On the fragments of paint found in the lower part of the Great Pyramid, we note the presence of large incisions, generally underlined by a black line which was employed to separate two colours. The paint was applied after the incision on the clay plaster. Among the Great Pyramid paint samples, we found some with a thin white 

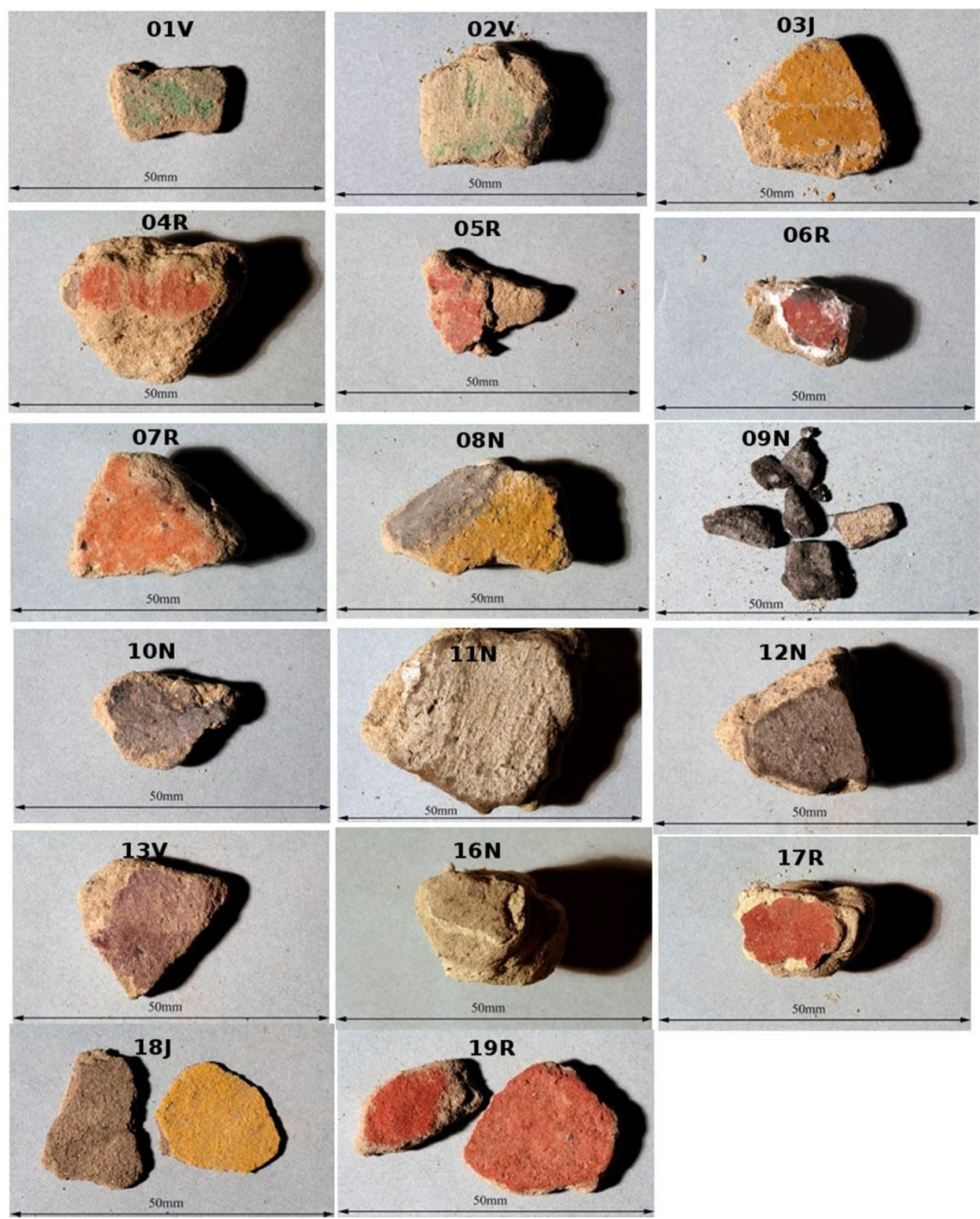

som

Fig. 3 Samples of mural painting from Cahuachi, Nasca. Photos: Dominique Bouchardon (LRMH)

layer (plaster or whitewash) applied to the base plaster, and on which the pictorial layer was executed. In some cases, several layers of paint overlap one another or are separated by a layer of plaster. This recalls the painting practices used by northern cultures. The samples were chosen among the many fragments detached from the wall. We have chosen them with the aim of getting the most complete paint stratigraphy as well as the different colours and types of coatings.
The samples from our study were taken from three areas of Cahuachi (Fig. 3). All the fragments of mural painting were taken from three distinct areas of the Great Pyramid (Y8): two sectors belonging to the upper platforms of the pyramid (samples 16N, 17R, 18J, 19R) and a sector in the lower part of the pyramid (samples $01 \mathrm{~V}$, 02V, 03J, 04R, 05R, 06R, 07R, 08N, 08J, 09N, 10N, 11N, $12 \mathrm{~N}, 13 \mathrm{~V})$. 
By observing the thickness of the coating on the fragments taken on site, we can distinguish a thin layer on the surface for the majority of the samples. The stratigraphy generally displays a first, coarser layer, which essentially has the function of equalizing the surface of the wall, and a second one, thinner and smoother, intended to receive the paint.

\section{Methodology}

\section{Stratigraphic sections}

The observation of samples in the form of stratigraphic sections was done first. Thus, tiny samples (about $1 \mathrm{~mm}^{2}$ ) were taken from the fragments in order to observe the different superimposed layers of paint and coating. The samples were placed in a non-pre-accelerated polyester resin (H59). The resin was then eroded gradually until the sample was flushed.

Because many fragments easily disintegrate, sometimes two complementary samples were taken to obtain the whole stratigraphy. Some painted plaster fragments have two juxtaposed colours easily separating from each other; therefore, they have been also prepared as separate fragments $(04 \mathrm{R}$ and $04 \mathrm{~N} ; 08 \mathrm{~J}$ and $08 \mathrm{~N})$. Only sample $01 \mathrm{~V}$ containing the two pictorial layers was successfully included in the polyester resin without splitting.

All the samples were studied under an optical microscope and at the SEM-EDX, which made it possible to visualize the stratigraphy and to obtain the elementary composition of each paint layer and that of the support coating of all the samples.

\section{Scanning electron microscopy and elemental analysis by EDX}

The nineteen stratigraphic sections were observed and then analyzed using a scanning electron microscope (SEM-EDX).

The electron microscope used was a JSM $5600 \mathrm{LV}$ (JEOL) coupled to an EDX Pentafet Link 6587 probe (Oxford Instruments). The observation of the pictorial layers in backscattered electrons was carried out without the use of metallization by working with a partial vacuum (pressure of $17 \mathrm{~Pa}$ ) at an accelerating voltage of $15 \mathrm{kV}$. The obtained data was processed with Inca software (Oxford Instruments).

\section{Raman micro-spectroscopy}

For the Raman spectroscopy analyzes, carried out directly on the raw samples, we used two complementary devices.

The first of them was a RM 2000 Raman dispersive micro-spectrometer (Renishaw) with two monochromatic sources $(633 \mathrm{~nm}$ and $785 \mathrm{~nm}$ ) and the second was a Labram IB micro-spectometer (Horiba Jobin-Yvon) with a monochromatic source of $532 \mathrm{~nm}$. Both devices are equipped with a barrel fitted with density filters to attenuate the power of the incident laser beam received by the sample. With the $100 \times$ magnification used, the spot size was $1 \mu \mathrm{m}^{2}$. Spectra are obtained with an acquisition time of $30 \mathrm{~s}$ and an accumulation of at least five spectra for the 532 and $633 \mathrm{~nm}$ lasers, and up to 20 spectra for the $785 \mathrm{~nm}$ laser. For each particle type, ten analysis points were analyzed on areas with the same microscopic characteristics. No filter was used for the acquisition of spectra from reference pigments.

\section{Fourier transform infrared spectroscopy}

The FTIR analyzes were carried out with the IR 2000 spectroscope (Perkin-Elmer) equipped with DTGS detector. The analyses were performed in transmission mode after preparing the pictorial layer samples in $\mathrm{KBr}$ pellets. The acquisitions of spectra were done in the spectral interval range 4000 to $400 \mathrm{~cm}^{-1}$ with $4 \mathrm{~cm}^{-1}$ resolution. The Spectrum software (Perkin-Elmer) was used to control the instrument and process the data.

\section{Reference pigments}

Several mineralogical studies were carried out in Peru [26-28]. They give localizations of ores deposits and determine the various minerals present on the territory. These studies also indicate the mineral compounds which could have been exploited by pre-Hispanic civilizations, in particular the pigments [24].

Five local pigments, extracted from different deposits in the region and used to make copies of old polychrome ceramics, were obtained from a potter in the town of Nasca. They consisted of a green stone, a black stone, and a second black speckled with red, as well as reddish orange and yellow powdery earth. Each pigment was analyzed in Raman spectroscopy and in elemental energy dispersion analysis (EDX).

According to the results obtained from Raman spectroscopy, the green stone was identified as clinoatacamite $\mathrm{Cu}_{2}(\mathrm{OH})_{3} \mathrm{Cl}$ (monoclinic), characteristic of the Peruvian and Chilean coastal desert. It is often associated with the atacamite $\mathrm{Cu}_{2}(\mathrm{OH})_{3} \mathrm{Cl}$ (orthorhombic) and the paratacamite $\mathrm{Cu}_{3}(\mathrm{Cu}, \mathrm{Zn})_{2}(\mathrm{OH})_{6} \mathrm{Cl}_{2}$, which is typical of the south coast region, is particularly found in the copper deposits of the Mina Justa in Marcona [29]. Clinoatacamite is attested at Lily's mine in the Pisco region [30].

The black and red stone was found to be hematite, containing a few grains of quartz. When it was ground to powder for analysis, it turned purple. Black stone is a complex rock made up of quartz, feldspar, clay and hematite. The yellow powder seems to correspond to a kind 

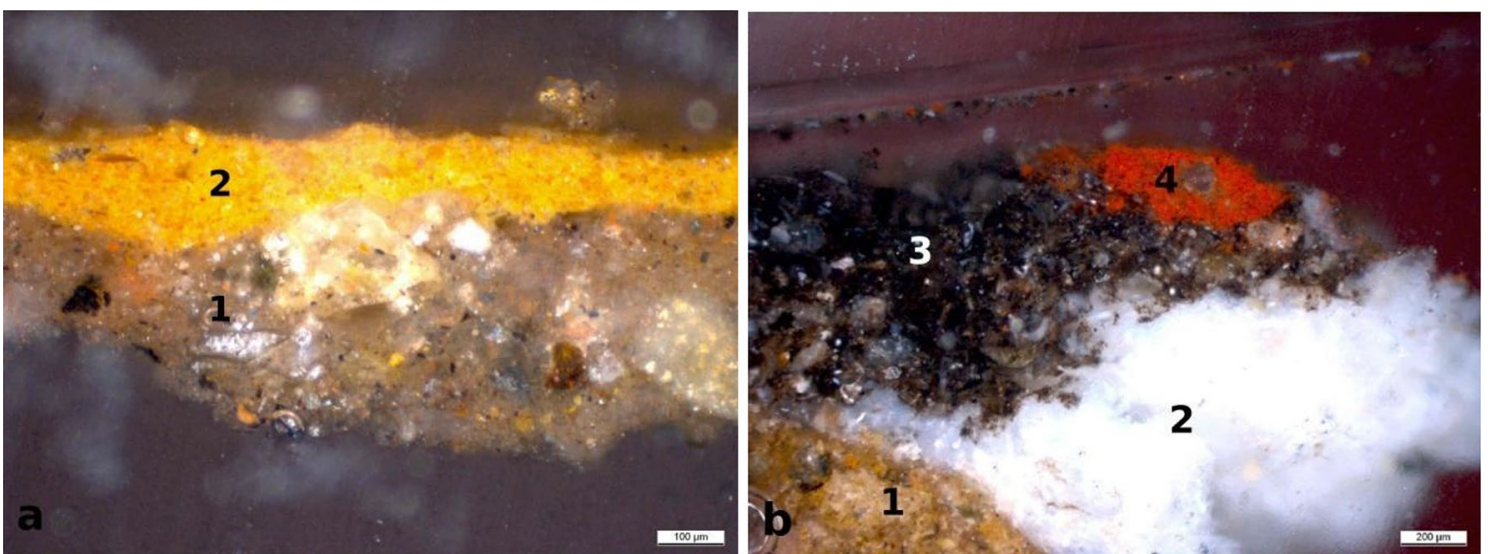

Fig. 4 a Cross-section of the $03 \mathrm{~J}$ yellow paint sample with a thick yellow pictorial layer (2) applied on the coating (1). b Sample 06R, with a red pictorial layer (4) on a black pictorial layer (3), itself on a white layer (2)

of limonite: a combination of several minerals with goethite, iron oxides and feldspar. The orange-red powder is clay containing hematite and sparse grains of sand.

\section{Results}

\section{Stratigraphic observations}

The majority of samples have a single pictorial layer (Fig. 4a) but those from sector Y8 Exp135 present the direct superimposition of coloured layers (Fig. 4b).

The superimposition of the pictorial layers suggests the presence of repaints which would not correspond to the initial pattern, but it could simply be juxtaposed paintings overlapping at the colour junction. In the case of the red paint spot on a black background of sample 06R, it could correspond to a detail directly painted on the surface of an initial drawing.

On the other hand, for the samples from sectors Y8 Exp 133 and 138 (16N, 17R, 19R), some have been repainted, this time applied to a new layer of plaster (Fig. 5).

These two sectors are located in the upper part of the Great Pyramid while the Exp135 sector is more eccentric. It is possible that this difference in the technique of applying the pictorial layers (with or without intermediary layer of a coating) may correspond to different construction phases, since the samples taken from the first two sectors correspond to the third construction phase and that the samples from the Exp 135 sector belong to phase 4 .

On the other hand, upon observation, there is a difference in texture of the white pictorial layers depending on the sector to which the samples belong. In the samples of the Exp 135 sector, the white layer always applied under the black layer, is homogeneous and consists mainly of white transparent crystals. On the
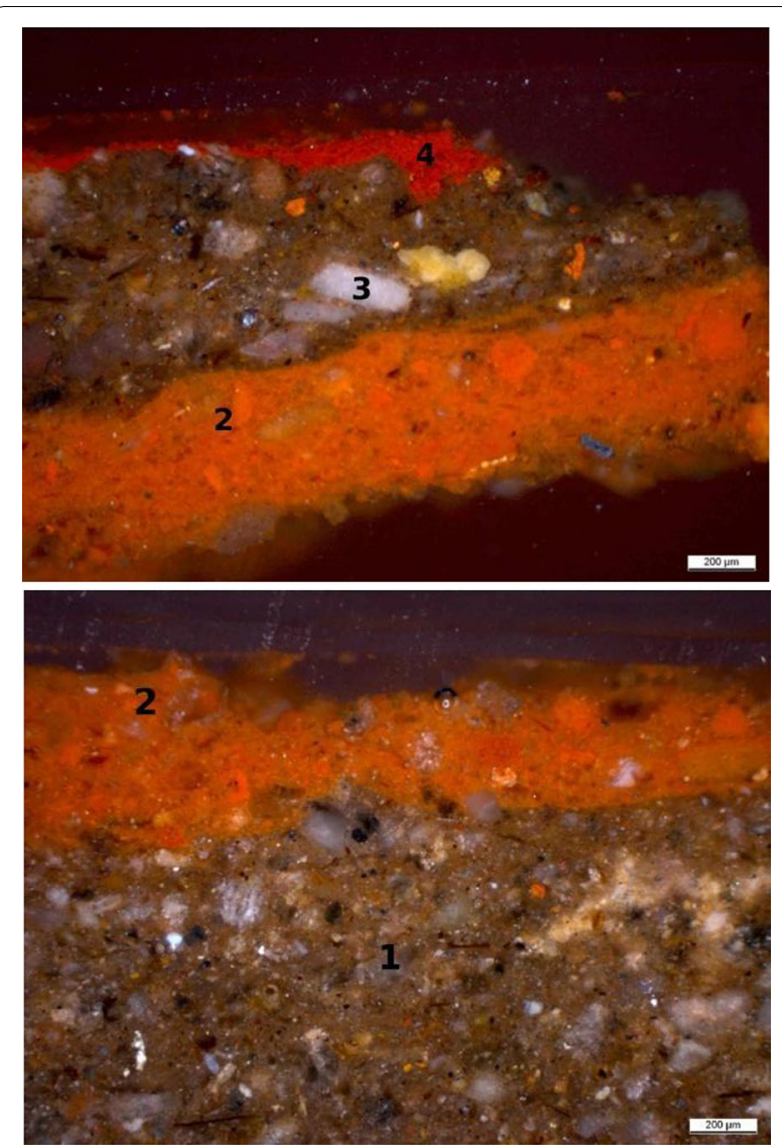

Fig. 5 Sample 19R, sector Y8 Exp 133. For reasons of cleavage between the layers, the complete stratigraphy was reconstructed using two complementary cross-sections. They display the application to a coating (1) of a thick orange-red layer (2) to which a layer of coating (3) has been applied again and then a thin red layer (4) 


\section{a}
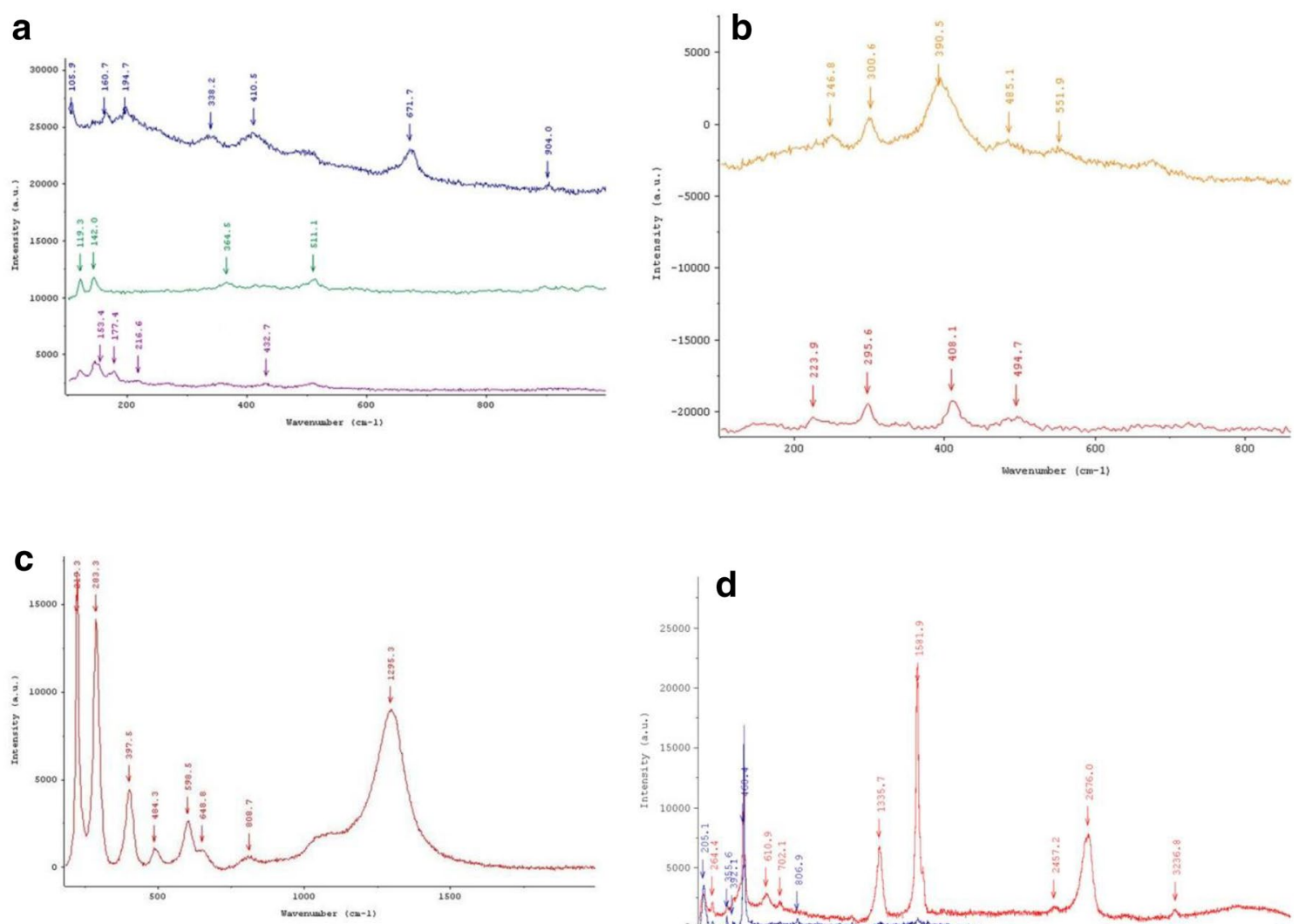

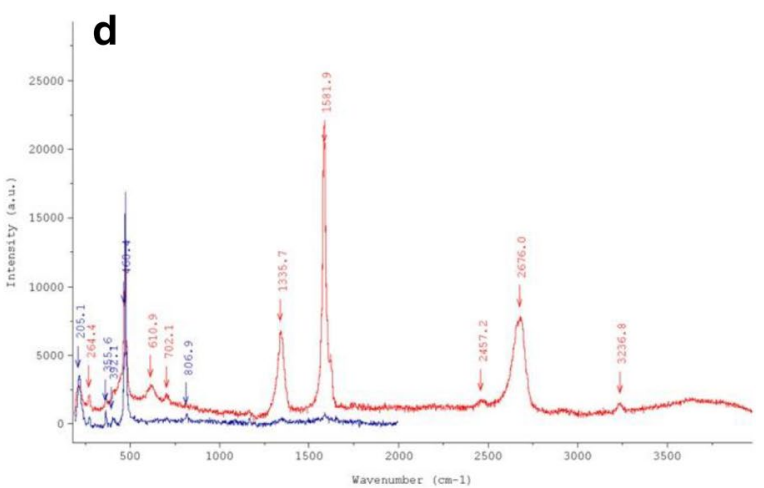

Fig. 6 Raman spectra. a The green paint in sample 02V contains malachite (purple), paratacamite (green) and chrysocolla (b/ue). Laser: $785 \mathrm{~nm}$. b In yellow paint 03J, goethite $\left(247,300,390,485,552 \mathrm{~cm}^{-1}\right.$ ) (orange) and hematite $\left(224 ; 295 ; 408 ; 495 \mathrm{~cm}^{-1}\right.$ ) (red) have been identified, laser: $532 \mathrm{~nm}$. $\mathbf{c}$ The purple pictorial layer of the $13 \mathrm{~V}$ sample contains hematite, laser: $785 \mathrm{~nm}$. d The analyses of black paint $06 \mathrm{R}$ show presence of graphite (red, laser $514 \mathrm{~nm}$ ) and quartz (blue, laser $785 \mathrm{~nm}$ )

contrary, in the samples from sector 133, the white layer has a cream colour and contains many aggregates of various colours. The other pictorial layers do not present any major differences between the sectors.

\section{Green paint}

The green paint was analyzed on three samples $(01 \mathrm{~V}$, $02 \mathrm{~V}, 08 \mathrm{~N}^{1}$ ), belonging to sector Exp 135, eccentric sector of the Great Pyramid. The grains in this paint are quite large (from 20 to $400 \mu \mathrm{m}$ ).

The SEM-EDX analysis shows for these layers the systematic presence of copper, sometimes associated with chlorine, sometimes with silicon. So, the detected compounds could be copper chloride (paratacamite, clinoatacamite, atacamite) or copper silicate (chrysocolla) or a mixture of these compounds.

\footnotetext{
${ }^{1}$ This sample is principaly black and yellow but it shows some traces of green paint.
}

The Raman spectroscopy analysis completes these first results by highlighting three distinct minerals (Fig. 6a): the paratacamite $\left(119,142,364,421,511 \mathrm{~cm}^{-1}\right)$ [31], the malachite $\left(153,177,216,356,432 \mathrm{~cm}^{-1}\right)$ [32] and the chrysocolla $\left(160,194,338,410,671 \mathrm{~cm}^{-1}\right)$ [33]. It is possible that these minerals may come from the same copper deposit.

\section{Red, yellow and purple paints}

The elemental compositions of red, orange and yellow paints are similar.

The major presence of aluminum and silicon can correspond to clay or an aluminosilicate (feldspar). Other minor elements have been identified by EDX: $\mathrm{Fe}, \mathrm{Ca}, \mathrm{S}$, $\mathrm{Na}, \mathrm{K}, \mathrm{Mg}$ and $\mathrm{Cl}$.

The presence of these elements, and in particular iron, may indicate that it is a clay more or less charged with iron oxides, such as goethite and hematite identified by Raman spectroscopy (Fig. 6b) [31, 32] which are the source of the coloration. The detection of other elements 
points out the presence of other compounds in colours, like anhydrite or gypsum, calcite, etc.

The colour of the pigments purple and red, is probably due to the presence of hematite but of different particle size.

The Raman spectroscopy analysis of the 13V violet paint, for which the iron concentration is higher, revealed the presence of hematite as a major compound (Fig. 6c). The spectra obtained from this sample presents a slight shift $\left(219,283,398,484,598 \mathrm{~cm}^{-1}\right)$ and a broad band at $1295 \mathrm{~cm}^{-1}$ that could be due to the presence of another element not identified or corresponds to a two magnoneffect [32].

\section{Black paint}

The elemental analysis of black paint samples $(06 \mathrm{R}, 08 \mathrm{~N}$, $09 \mathrm{~N}, 10 \mathrm{~N}, 11 \mathrm{~N}, 12 \mathrm{~N}, 16 \mathrm{~N}$ ) shows a composition similar to the reds and yellows: $\mathrm{Al}, \mathrm{Si}, \mathrm{K}, \mathrm{Na}, \mathrm{S}, \mathrm{Ca}, \mathrm{Mg}, \mathrm{Cl}, \mathrm{Fe}$. The absence of manganese shows that manganese oxide is not the source of the black colour. On the other hand, the black pigment could be a black iron oxide such as $\gamma-\mathrm{Fe}_{2} \mathrm{O}_{3}$ maghemite or magnetite $\mathrm{Fe}_{3} \mathrm{O}_{4}$. It could also be carbon black like charcoal since the provision of plant material was abundant in Nasca times, especially the huarango (Prosopis pallida) [34]. For sample 06R, no iron oxide was identified byRaman spectroscopy, but as well as carbonaceous material for black particles (1335, 1581, 2457, 2676, $3236 \mathrm{~cm}^{-1}$ ) (Fig. 6d). Indeed, vibrational modes at $1335 \mathrm{~cm}^{-1}$ and $1581 \mathrm{~cm}^{-1}$ are bands associated with the $\mathrm{D}$ and $\mathrm{G}$ normal modes in graphite respectively. The $\mathrm{D}$ and $\mathrm{G}$ band intensities ratio and the second-order spectrum can be used to determine amorphization stages. Thus, the well defined and intense peak at $1581 \mathrm{~cm}^{-1}$ and the presence of three second-order peaks $\left(2457,2676,3236 \mathrm{~cm}^{-1}\right)$ indicate a well crystallized form of graphite but disorder-induced peaks at 1335 and $1620 \mathrm{~cm}^{-1}$ indicate a weak amorphization [31, 35, 36]. These black particles seem to correspond to microcrystalline form (disordered) of graphite but does not exclude the presence of charcoal, as the major Raman bands of both carbon forms could be superimposed. The (partially) graphitized charcoal seems to be a possible source of graphite signal. This matter certainly was accessible, in the contrary of graphite from geological sources, as no historical evidence was found of the existence and exploitation of such a mineral in the region. This hypothesis need to be checked further, on other paintings in Cahuachi and around this site.

\section{Preparation layer}

With regard to the white layer, five samples were analyzed $(06 \mathrm{R}, 09 \mathrm{~N}, 11 \mathrm{~N}, 16 \mathrm{~N}, 17 \mathrm{R})$. Each one presents a white layer beneath the painted surface. This layer could be a preparation to receive the painted decoration or a pigment layer. At this stage, we cannot distinguish between the two options. The analyses reveal the use of two white layers of different natures.

The first concerns the samples from the Exp 135 sector $(06 \mathrm{R}, 09 \mathrm{~N}, 11 \mathrm{~N})$ and consists mainly of silicon as shown by the EDX analyses (Fig. 7a): We have not succeed to identify it precisely by Raman spectroscopy but FTIR analyses indicate that it is amorphous silica (Fig. 9a).

Also, few particles of andesine ( $\mathrm{Na}, \mathrm{Ca})\left[\mathrm{Al}(\mathrm{Si}, \mathrm{Al}) \mathrm{Si}_{2} \mathrm{O}_{8}\right]$ and of feldspar were identified by Raman spectroscopy. The spectum of feldspar was compared to some references in the database such as sanidine $(\mathrm{K}, \mathrm{Na})[(\mathrm{Al}, \mathrm{Si})$ $\mathrm{Si}_{2} \mathrm{O}_{8}$ ] or petalite ( $\mathrm{LiAlSi}_{4} \mathrm{O}_{10}$ ) but the latter contains lithium of which we have found no trace in elemental analysis (Fig. 8).

The second white layer is characterized by various elements identified by EDX: Al, Si, Ca, S, Cl, Na, Mg, K, Fe. The Raman analyses did not allow a more precise identification. According to the elemental analyses, the white layer could correspond to an aluminosilicate mixed with a little calcium sulphate. Indeed, the FTIR analyses confirm the presence of gypsum and probably of a clay (Fig. 9b). Iron was also identified by the EDX analyses and could be naturally present in this rock or come from neighboring red and yellow paints. These compounds were identified on two samples (16N and 17R) which belong to the Exp 133 sector (Fig. 7b).

All of the analyzes allowed us to draw up a list of pigments in the paint layer and the composition of the preparation layers present in the samples of wall paintings in Cahuachi (Table 1).

\section{Discussion \\ Origin of pigments}

The samples from this study are among the few examples of murals on the south coast of Peru and are among the oldest after the Animas altas wall painting.

The pigments were probably extracted from deposits close to the Nasca sites. Previous archaeological research has shown that mining had already been practiced during the Nasca era, notably Mina Primavera and the Mina Ballena (Fig. 1). Nasca people extracted hematite from Mina Primavera [37]. Excavations near the Ballena mine reveal the existence of mining from the Early Nasca to the Late Horizon. This site was occupied by small groups of miners for short periods of time, when they mined and extracted minerals from local deposits in the vicinity [38]. Given the quantity of mines or deposits in the lower part of the Andean foothills, relatively close to Cahuachi and other archaeological sites, it is possible that other sites had the same function as that of La Ballena. The 

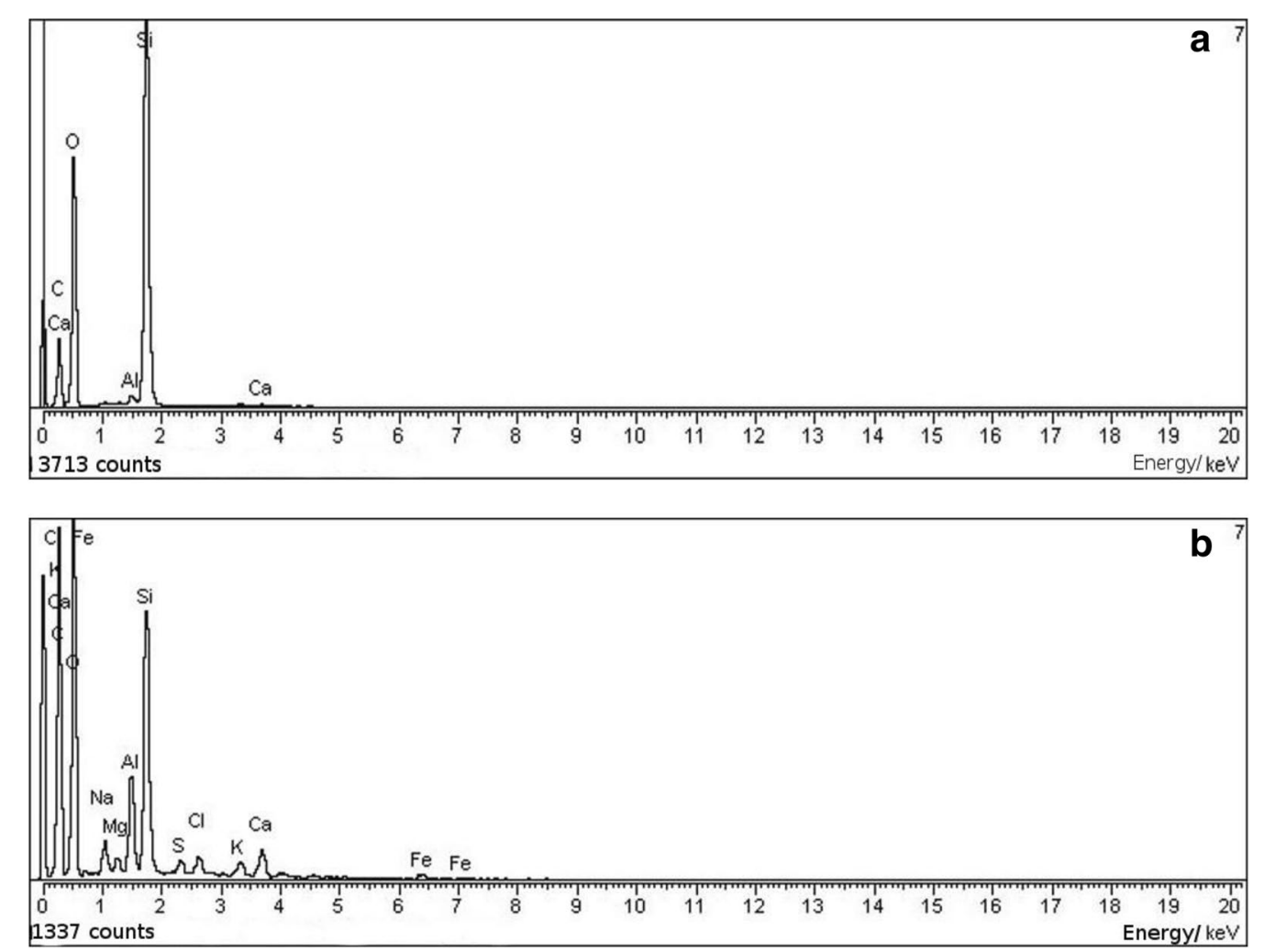

Fig. 7 a Typical EDX spectrum of the white layer of sample 06R. b Typical EDX spectrum of the white layer of the $16 \mathrm{~N}$ sample
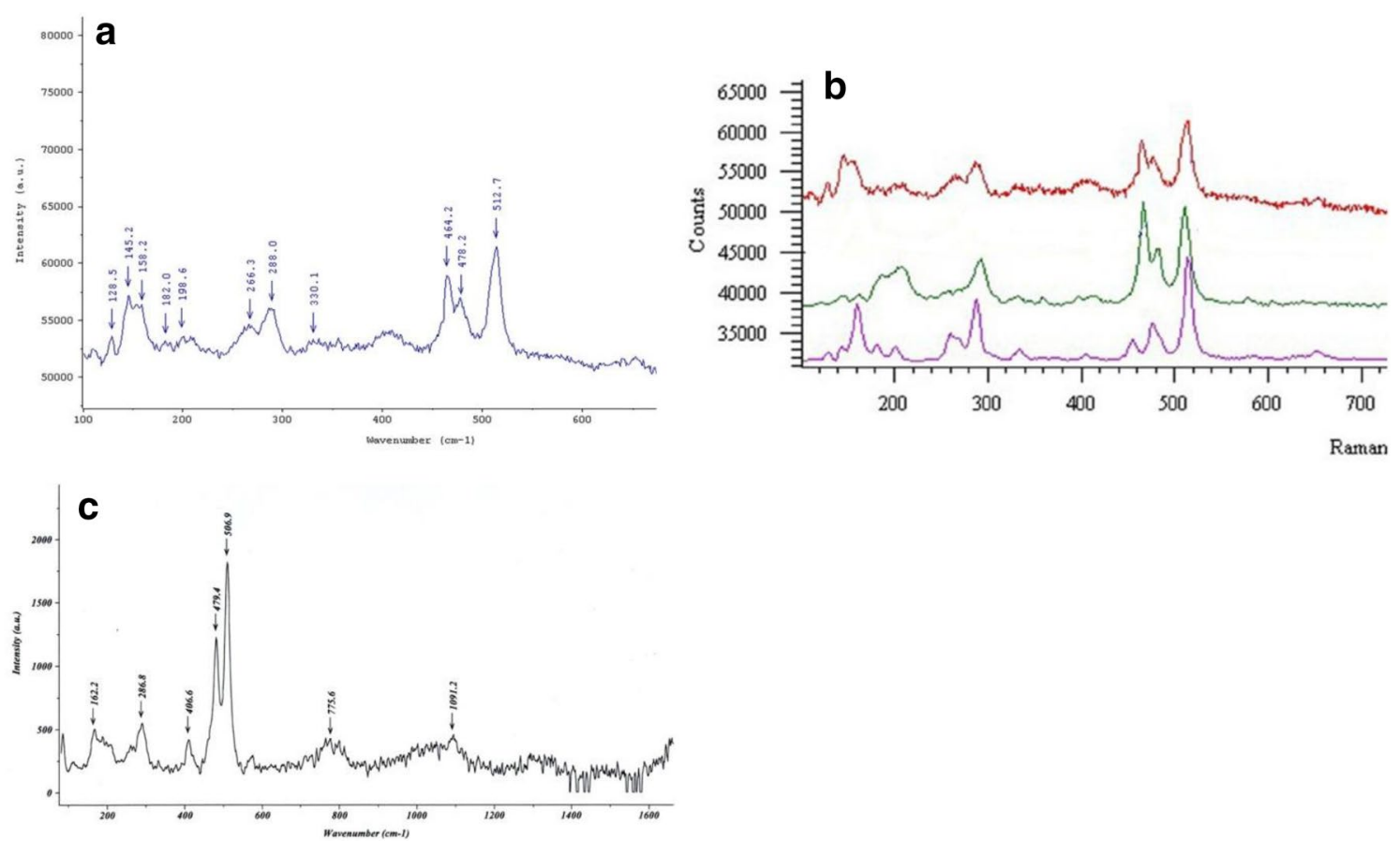

Fig. 8 a Raman spectrum obtained on a white grain of 06R white paint. b It (red) is similar to the spectrum of a feldspar, such as sanidine ( (green), or petalite (purple). c Spectrum of a slightly greenish area of white paint 06R which corresponds to andesine, a plagioclase. All spectra laser $514 \mathrm{~nm}$ 


\section{a}

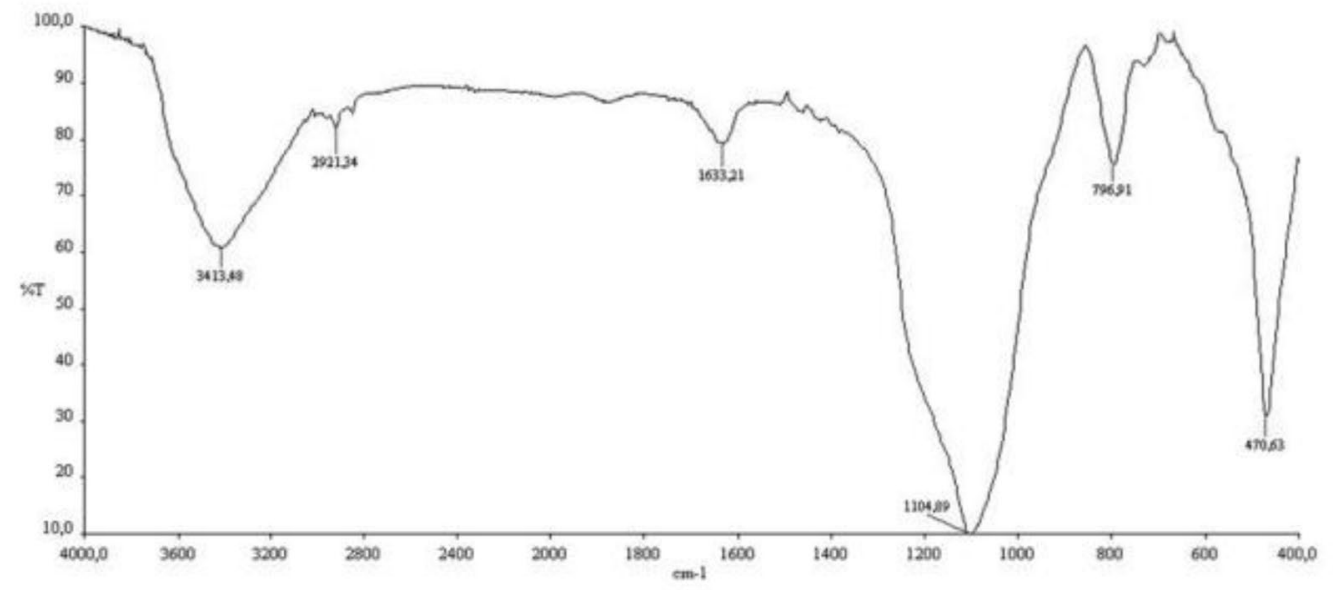

b

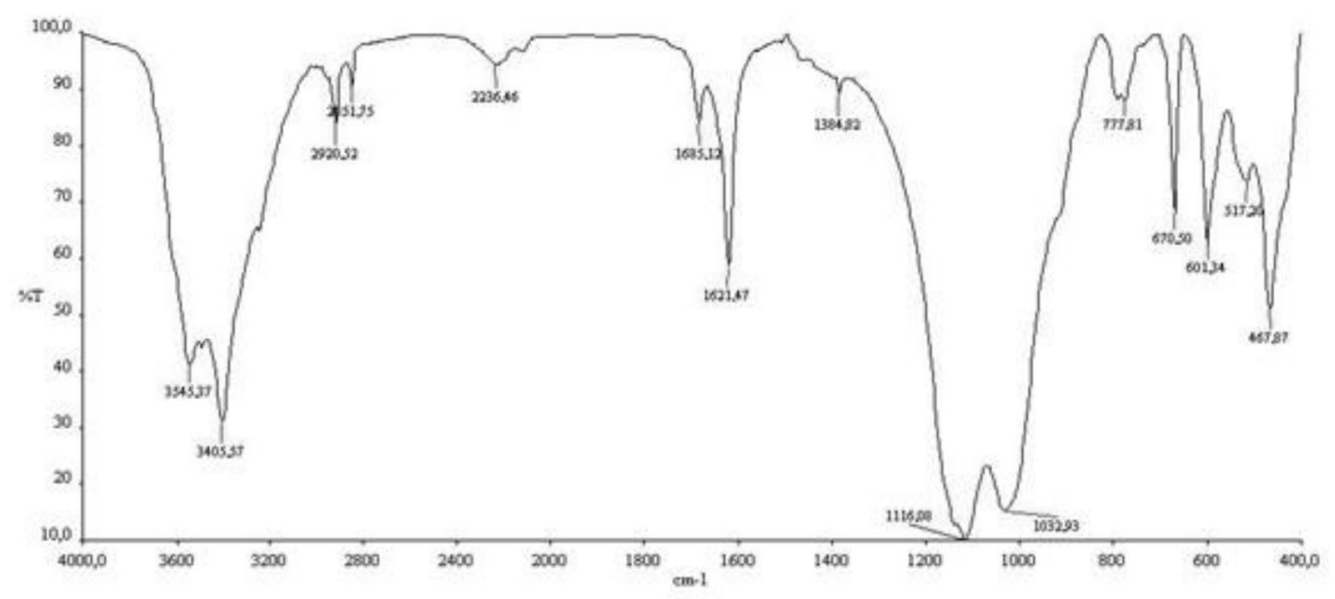

Fig. 9 a FTIR Spectrum obtained from the white layer of 06R sample which is characteristic of amorphous silica $(470,797,1105,1633,2921$, $\left.3413 \mathrm{~cm}^{-1}\right)$. b FTIR Spectrum from the white layer of $17 \mathrm{R}$ sample showing presence of gypsum $(3545,3405,1685,1621,1116,670 \mathrm{et} 601 \mathrm{~cm}-1)$ and probably quartz $\left(777,785 \mathrm{~cm}^{-1}\right)$ and clay $\left(1032,950 \mathrm{~cm}^{-1}\right)$

Table 1 Identified mineral materials

Stratigraphy

Green paint

Yellow paint

Orange paint

Red paint

Purple paint

Black paint

Preparation/white paint

\section{Identification}

Paratacamite, malachite et chrysocolla

Yellow ocher

Orange ocher (hematite and clay)

Red ocher (hematite and clay)

Hematite and clay

Graphite/charcoal, aluminosilicate and quartz

White clay and calcium sulfate

Silica

Clay loam

\section{Samples}

$02 \mathrm{~V}, 08 \mathrm{~J}$

03J

07R, 19R

04R

$13 \mathrm{~V}$

06R

$16 \mathrm{~N}, 17 \mathrm{R}$

06R

All samples 
proximity of these deposits has certainly facilitated the use of pigments by pre-Hispanic painters and for traditional Nasca ceramists today.

According to the results, the red and yellow paintings of Cahuachi were probably made with earth rich in iron oxides: hematite $\left(\alpha-\mathrm{Fe}_{2} \mathrm{O}_{3}\right)$ and goethite $(\alpha-\mathrm{FeOOH})$. Indeed, sources of hematite and red and yellow ocher are abundant in the Nasca region. Sources of limonite, hematite and ferruginous clays are known near the city of Ica $[26,27]$, as well as sedimentary rocks intensely coloured by iron oxides in the lower valley of Ica [26]. Further to the south, ochres and iron oxides are abundant in and around the Marcona mine, one of the largest deposits of iron on the coast [30, 40,41]. Between Ica and Marcona, the Nasca region has its own deposits. In fact, in the north of the department, there are significant deposits of ferrous minerals including hematite and limonite [39]. It is in the north of the Ingenio valley, at the foot of the first Andean mountains that the Mina Primavera is located, a hematite mine, which has been exploited since the Nasca era [37]. Thus, it seems that ancient civilizations were able to easily obtain red and yellow pigments thanks to the abundance of ochres and iron oxides in the region.

On the other hand, the analysis of samples of Cahuachi green paint shows that painters used several copper compounds such as paratacamite, malachite, chrysocolla. Indeed, copper ores are abundant on the coast, present in the form of carbonates, silicates and chlorides, and are sometimes intimately mixed, as it is the case in the mines of Canza and Tingue (Ica) [26] (Fig. 1). The presence of this type of composite deposits in the region could explain why thanks to the Raman analysis we identified three distinct minerals for the same fragment of paint. Other copper deposits with their secondary minerals are known near Pisco (Lily Mine, Mina Eliana, Cincocruces), Marcona (Mina Justa) and between Ica and Palpa (Proyecto Chavez) [29]. But the deposits of copper ores are particularly concentrated in the "copper fringe south of the Pacific slope", which borders the basin of the Rio Grande de Nasca. There, one finds green copper minerals (malachite, atacamite, clinoatacamite, paratacamite, chrysocolla) which could be used as pigments once reduced to powder [28, 39]. In fact, a recent study has shown that several sites in the Nasca region were exploited during the time of the Early Intermediary Period: Mina Pataraya and Mina Vetila are copper mines located upstream of the Nasca river, on the slopes of the quebrada Tierras blancas [42] (Fig. 1).

The black paint could not be identified precisely: the composition of the material remains complex. The black coloration may be due to the presence of graphite or rather graphitized charcoal identified on the black particles. It could be graphite mixed with a rock composed of many chemical elements, however sources of graphite are not known in the Nasca region. This rock is reminiscent of the reference black stone used by the Nasca ceramist as a black pigment: a complex of quartz, feldspar, clay and hematite.

Finally, the analyses made it possible to differentiate two types of white paint: a siliceous material and an alumino-silicate-probably a clay-mixed with calcium sulphate. The latter could be present naturally in the extracted white rock or be added a posteriori as filler. On the southern coast, calcium sulphate can be found in the form of gypsum and anhydrite in several places, espacially between Pisco and Ica [26, 27].

Among the pigments identified, several of them were used by the other pre-Hispanic cultures on the coast, in particular, red and yellow ochres, hematite and goethite as well as copper green pigments (chlorides, carbonates, copper silicates).

The nature of black and white pigments differs more depending on the region and cultures. With regards to black paint, the use of graphite is only mentioned once on the site of Chornancap (700-1532 AD) [4] and magnetite was identified at Pañamarca (500-900 AD) [30], both on the far north coast. For white paints, clay has been used several times alone or with a filler, notably at Huaca de la Luna (north coast, Early Intermediate Period, Middle Horizon) and Tambo colorado (south coast, Late Intermediate Period) $[4,43]$, but no results have demonstrated the use of a siliceous material. This pigment could then be considered characteristic of Cahuachi.

\section{Technical considerations}

This preliminary study, carried out on the Cahuachi murals, allowed us to identify some of the main materials used (Table 1) by the Nasca painters but also to partly understand the pictorial techniques used to adorn the buildings of Cahuachi.

The first observations of the fragments seem to confirm the hypothesis of a painting a secco (on dry support): the low calcium content in the coating and the poor adhesion of the layers allow us to rule out the hypothesis of the fresco. However, the FTIR analyses did not reveal the presence of any organic binders. On the Mochica site, the Huaca de la Luna, decorated with paintings dating from the 3rd to the eighth century AD, analyses of binders revealed the use of cactus gum and another binder of unspecified animal origin [7]. In that case, the technique used was a distemper. For the moment, this is the only identification of a binder in the murals roughly contemporary with those of Cahuachi, but this is a site on the north coast, and it is difficult to say whether the technical knowledge could have been similar or not. 
Table 2 Major differences observed on the murals in each sector

\begin{tabular}{|c|c|c|c|}
\hline \multirow[t]{2}{*}{ Distinctive features } & \multicolumn{2}{|l|}{ Phase 3} & \multirow{2}{*}{$\begin{array}{l}\text { Phase } 4 \\
\text { Y08 } \operatorname{Exp} 135 \\
1 V, 2 V, 3 J, 4 R, 5 R, 6 R, 7 R, 8 N, 9 N, 10 N, 11 N, 12 N, 13 V\end{array}$} \\
\hline & $\begin{array}{l}\text { Y08 Exp133 } \\
16 \mathrm{~N}, 17 \mathrm{R}, 18 \mathrm{~J}\end{array}$ & $\begin{array}{l}\text { Y08 Exp138 } \\
19 R\end{array}$ & \\
\hline Repaint with coating layer & Yes & Yes & No \\
\hline White coating & Clay and gypsum & Clay and gypsum & Siliceous material \\
\hline Colours & Black, red, yellow, & Red & Black, white, purple, red, orange, yellow, green \\
\hline Pigments & Unidentified black, red ocher, & Red ocher & $\begin{array}{l}\text { Graphite/charcoal, white siliceous material, hematite, red ocher, } \\
\text { orange ocher, yellow ocher, paratacamite with malachite and } \\
\text { chrysocolla }\end{array}$ \\
\hline
\end{tabular}

Based on the observations and analytical results, the preparation of the support wall was simple. In most cases, the walls were simply smoothed using the same silt material used for the adobe, then the paint was applied directly. However, five fragments $(06 \mathrm{R}, 09 \mathrm{~N}, 11 \mathrm{~N}, 16 \mathrm{~N}$, $17 R)$ from the upper and lower parts of the Great Pyramid have a white coating which was applied to the surface of the walls before painting. Finally, in sector Y08 Exp 135 (phase 4), fragments attest to the making of incisions inscribed on the painted walls. These incisions seem to constitute a first engraved sketch. It generally delimits two distinct colours which will be applied afterwards. On these incisions black lines were applied, covering or underlining them. The colour palette of the paintings in sector 135 seems to be as varied as that of contemporary cultures in the north or that of the Inca paintings of the southern coast.

Finally, the study of the mural painting fragments, highlighted differences in the areas of discovery of the samples (Table 2). Thus, the nature of the white coating constitutes a distinctive feature. Indeed, on the walls at the base of the pyramid (part 4), the white coating used is a compound with a high silica content, a hydrated silicate, while the white coating used for the upper part (phase 3) is characterized by the presence of gypsum. In addition, some paints were completely covered with a coat of plaster and repainted. These repaints are present only on two fragments (samples 17R, 19R) from the sectors located in the upper part of the pyramid (Exp133 and 138). These areas were probably the first to be painted during construction phase 3 , and were subsequently repainted.

Finally, there is a limited use of colours for the upper sectors, but the very small number of fragments discovered in sectors Exp133 and 138 does not allow us to know the number of colours originally used. According to the few fragments found, the palette consists of red (sector Y08 Exp138), yellow and black (sector Y08 Exp133). If we consider the dating of the paintings, with those of the Exp138 and Exp133 sectors older than the paintings of the Exp135 sector, it seems that the colour palette has been enriched over time.

Furthermore, we note another difference among the composition of pigments: in fact, some paint samples contain small quantities of calcium sulphate (red: 17R, blacks: $16 \mathrm{~N}$ and $10 \mathrm{~N}$, yellows: $8 \mathrm{~J}$ and 3J, whites: $16 \mathrm{~N}$ and 17R). This compound can be found in certain paintings in phases 3 and 4, located in the upper part of the pyramid (Exp 133) and in the paintings in the lower part (Exp 135). Gypsum or anhydrite are both natural calcium sulfates, which may have been added by the painter as a filler or as a "diluent" to obtain light tones, but they can also naturally occur in the deposits of minerals that served as pigment.

During the 2007 excavation campaign, new pieces of painted walls (green, emerald green, blue, black, red, and brown) were discovered at the feet of building walls. Among these fragments, two colours appear for the first time: blue and brown. On the other hand, rags impregnated with paint were also discovered with the paint fragments that had fallen at the foot of the walls. They were probably used to paint the walls, like the large cotton pads (broquel) used to brush the walls in Pachacamac site $[4,7]$.

\section{Sharing of pigments and recipes with ceramists and textile painters?}

The paint can be applied on many supports. The Nasca have thus developed different techniques for painting on walls, ceramics and textiles.

By comparing the pigments of Nasca ceramics [44, 45] with those used for textiles [24] or wall painting, we note that the pigments chosen for ceramics are not used in other pictorial techniques, except ochres and iron oxides, universal pigments. Both organic dyes and copper-based green pigments deteriorate at high temperatures and were therefore not used. Ceramic, involving a firing of pigments, makes it impossible to use certain minerals and limits the range of colours used. Another example is the blacks of manganese-based ceramic, which does 
not correspond to the blacks used in painting on textiles (charcoal) or in wall painting (aluminosilicate plus graphite/charcoal).

On the other hand, the green, black and blue pigments are not the same for painting on textiles as they are for wall painting. In addition, the preparation of the support is distinct and demonstrates the absence of influence: the murals are applied after the application of a plaster which smooths and homogenizes the surface of the wall to be decorated, while the irregular surface of the textile remains without prior treatment.

At last, the Late Paracas ceramics, made while the Nasca culture was emerging, were painted after firing which allowed more freedom in the choice of pigments. Thus, Paracas ceramists used red ocher and copperbased green pigments, as in Nasca wall paintings, but also organic blue and white pigments [46].

Therefore, ceramists, mural painters and textile painters shared the use of certain pigments, but each of them had their own recipe. Analyzes show that craftsmen have demonstrated a remarkable capacity for innovation. We can notice, by comparing Nasca murals, textiles and ceramic paints, that the use of pigments and their application are different skills.

\section{Conclusion}

The present study showed the first approaches to characterization of Nasca wall paintings from the Early Intermediate Period, on the site of Cahuachi.

These paintings are among the most ancient found in South Peru. The studied fragments dated from the 3rd phase (from 0 to $250 \mathrm{AD}$ ) and 4th phase (from 250 to $400 \mathrm{AD}$ ) of occupation period show many similarities between them, concerning their stratigraphy and the majority of pigments. The pigments are mostly originating from local resources like clays, iron oxides and copper minerals. However, the difference of composition of the white pigment between samples from respective constructive phases was observed on several samples and it may be therefore considered as a possible chronological marker. Also, copper minerals were found in green painting only from the 4th phase. The presence of copper minerals may be an additional marker, because up to now, we have found in the 3rd phase paintings only clays and iron oxides. This information needs to be further confirmed, exploring more widely the Cahuachi site or looking for painted plasters from future discoveries in South Peru.

Although the studied fragments are few, they constitute an important insight into the knowledge of preColumbian art in Peru in general and especially in wall painting history, because some already known examples of wall painting are remote from a geographical point of view, on the North or Central coast, or from a chronological point of view, being dated mostly from the Middle Horizon and Late intermediate Periods. The Cahuachi murals have similarities with the other pre-Hispanic murals known in Peru but they also have their particularities. For example, pigments of hematite, ochers and copper chloride or carbonate have been identified in many other sites. On the other hand, we recognize a greater variability in the use of white and black pigments according to the sites. For instance, the white pigment could be limestone (Tucume, Huaca Licapa, Pañamarca, Chornancap and La Mayanga in north coast), clay with lime (Tambo Colorado in south coast), or clay with gypsum like in the Huaca de la Luna (north coast) and Cahuachi. In addition, another white pigment was identified only in Cahuachi: a siliceous material. The black pigments used in pre-Columbian paintings could be: charcoal mixed both with quartz and feldspars (Huaca de la Luna), magnetite (Pañamarca), graphite and chalcosiderite (Chornancap), pyrolusite (La Mayanga), hematite (Pachacamac) and graphite with quartz as appears to be the case in Cahuachi.

The observations and analyses made in this study give first elements of knowledge on Cahuachi paint materials and techniques, but they need to be completed in the future by new discoveries to give a more complete view on the ancient wall painting art of the south coast of Peru.

Cahuachi's mural painters are specialists who first use red, yellow, black and white pigments and who, over time, will gradually expand the colour palette by following the same recipes but changing to white pigment.

According to the archaeometric studies on Nasca ceramics, textiles and murals paints there are differences in the choice of pigments, recipes and techniques depending on the paint application medium. Therefore, it seems that each trade does not relate to the others, is not influenced and does not exchange its recipes. We will talk about compartmentalization of activities. This suggests the existence of separate workshops with a particular technical language for each of these areas of paint application. This specialization of the craftsmen indicates that they probably constituted a social class apart as suggested by several scholars [11, 14-16].

\footnotetext{
Acknowledgements

The authors would address their thanks to Didier Brissaud (LRMH) for his assistance in FTIR analyses, as well as, Olivier Bobin (CIRAM), Jean-Luc Bruneel (ISM, University of Bordeaux 1) Stephan Dubernet (CRP2A, Bordeaux 3) and the company Renishaw, the geology laboratory of the University of Paris 5 for access to the various Raman instruments.
}

\section{Authors' contributions}

Nathalie Boucherie participated in the sampling, carried out the analyses by Raman spectroscopy, interpreted Raman spectra and wrote the text; Witold Nowik supervised the work, discussed the obtained results, structured and revised the manuscript; Nathalie Pingaud prepared and analyzed the 
cross-sections by SEM-EDX, interpreted EDX spectra and contributed to the revision of the manuscript. All authors have read and approved the final manuscript.

\section{Funding}

This study was carried out as part of an history Ph.D. thesis funded by a BD grant from CNRS.

\section{Availability of data and material}

Please contact the corresponding author for reasonable data requests.

\section{Declarations}

\section{Competing interests}

There are no financial and non-financial competing interests.

\section{Author details}

${ }^{1}$ Bordeaux, France. ${ }^{2}$ Laboratoire de Recherche des Monuments Historiques (LRMH), 29 rue de Paris, 77420 Champs-sur-Marne, France. ${ }^{3}$ Centre de Recherche sur la Conservation (CRC), USR 3224, Muséum national d'Histoire naturelle, CNRS, Ministère de la Culture, 36 rue Geoffroy Saint Hilaire, 75005 Paris, France. ${ }^{4}$ Present Address: Centre de Recherche et de Restauration des Musées de France, 14 quai François Mitterrand, 75001 Paris, France.

Received: 13 December 2020 Accepted: 13 May 2021

Published online: 27 May 2021

\section{References}

1. Strecker M. Recent rock art studies in Peru, in Rock art studies: news of the world, V, ed. Bahn P. Franklin N. and Strecker M, 2012, 329-337.

2. Astete F, Echevarría-López G-T, Bastante JM. Quilcas or rock art at the Historic Sanctuary of Machupicchu, Cusco, Peru: discovery and perspectives. Rock Art Res. 2017;34(1):25-39.

3. Morillas H, Maguregui M, Bastante J, Huallparimachi G, Marcaida I, GarcíaFlorentino C, Astete F, Madariaga JM. Characterization of the Inkaterra rock shelter paintings exposed to tropical climate (Machu Picchu, Peru). Microchem J. 2018;137:422-8.

4. Bonavia D. Mural Painting in Ancient Peru. Bloomington: Indian University Press; 1985

5. Uceda S, Mujica E, Morales R, editors. Investigaciones en la Huaca de la Luna 1997. Trujillo: Facultad de Ciencias Sociales,Universidad Nacional de Trujillo; 2000.

6. Muelle JC, Wells JR. Las pinturas del templo de Pachacamac, Revista del Museo Nacional, 1939, T.VIII, $n^{\circ} 2$, Lima, 265-82.

7. Wright V. Circulation des pigments sur le territoire Mochica: Côte nord

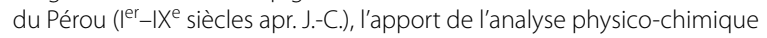
à la compréhension de l'organisation sociale, in : Territoires et économies . Paris : Éditions de la Sorbonne, 2010. DOl : https://doi.org/10.4000/books. psorbonne.5912.

8. Bachir-Bacha A. El Edificio de los Frisos de Ánimas Altas. Ser paracas en el valle bajo de Ica, Boletín de arqueología PUCP. 2017;22:191-225.

9. Strong WD. Paracas, Nasca and Tiahuanacoid Cultural relationships in South Coastal Peru, in Memoir of the Society for American Archaeology 13, Salt Lake City, American Antiquity, 1957, vol. 22, n4; part 2.

10. Rowe JH. Urban settlements in Ancient Peru. Berckeley: Nawpa Pacha; 1963. p. 1-27.

11. Silverman HI. Cahuachi in the ancient Nasca world. lowa: University of lowa Press; 1993.

12. Reindel M, Isla J. Los Molinos y La Muña. Dos centros administrativos de la cultura Nasca en Palpa, costa sur del Perú. Beïtrage zur Allgemeinen und Vergleichenden Archäologie. 2001;21:241-319.

13. Orefici G. Drusini A. Nasca, hipótesis y evidencias de su desarrollo cultural, CISRAP ed., Lima, Perú, 2003.

14. Llanos Jacinto D.O. Le bassin du Rio Grande de Nazca, Pérou. Archéologie d'un état andin, 200 avant J.-C. - 650 ans après J.-C., 2009, ed. Archaeopress, BAR International Series 1990.
15. Carmichael P. Nasca ceramics: production and social context, in Andean Ceramics: Technology, Organization and Approaches. MASCA Res Papers Sci Archaeol. 1998;15:213-31.

16. Vaughn K, Van Gijseghem H. A compositional perspective on the origins of the "Nasca cult" at Cahuachi. J Archaeol Sci. 2007;34:814-22.

17. Proulx A. Local differences and times differences in Nasca pottery. Berkeley: University of California Press. University of California Publications in Anthropology; 1968.

18. Sawyer AR. Early Nasca Needlework. London: Primitive Arts Ltd; 1997.

19. Frame M. Textiles de estilo Nasca. In: de Lavalle Vargas J. A. and de Lavalle de Cardenas R. eds. Tejidos Milenarios del Perú, Lima: Integra AFP, 1999, 261-310.

20. Silverman HI. The Paracas problem: archaeological perspective. In: Paul A editor. Paracas Art and Architecture, Object and Context in South Coastal Peru. lowa City: University of lowa Press; 1991. p. 349-416.

21. Orefici G, Cahuachi, El centro ceremonial en adobe más grande del mundo, in: Nasca, el desierto de los dioses de Cahuachi, 2009, 36-59.

22. Bachir-Bacha A, Dinámica y desarrollo de un centro ceremonial andino. El caso de Cahuachi. Arqueología y Sociedad, 2007, 18: 69-94.

23. Gavazzi A, La arquitectura de Cahuachi, in: Nasca, el desierto de los dioses de Cahuachi, 2009, 114-131.

24. Boucherie N, La couleur dans la civilisation Nasca : production tinctoriale et picturale, PhD thesis. Université de Lyon 2, 2014.

25. Bednarek R, Gąsior M, Łukaszewicz JW, Pokojska U, Investigation on the reasons of damage and conservation methods of adobe structures $\mathrm{In}$ : Daniel Kwiatkowski and Runo Löfvendahl eds. Proceedings of the 10th international congress on deterioration and conservation of stone, 1 , Stockholm : ICOMOS, 2004, 99-106.

26. Raimondi A. Minéraux du Pérou, Catalogue raisonné. Paris: Chaix et Cie; 1878.

27. Raimondi A, El Perú, Estudios mineralógicos y geológicos, Lima, 1983 $1-232$.

28. INGEMMET, Mapa geológico minero, cuadrángulos: Lomitas, Palpa, Nasca y Puquio, Lamina ${ }^{\circ}$ 5. Lima : Instituto Geológico minero y metalúrgico, 1994.

29. Database of Hudson Institute of Mineralogy. http://www.mindat.org/loc232161.html. Accessed 29 Nov 2020

30. Database of Hudson Institute of Mineralogy. http://www.mindat.org/loc6987.html. Accessed 29 Nov 2020.

31. Burgio L, Clark RJH. Library of FT-Raman spectra of pigments, minerals, pigment media and varnishes, and supplement to existing library of Raman spectra of pigments with visible excitation. Spectrochimica Acta Part A. 2001:57:1491-521.

32. Bouchard M, Smith DC. Catalogue of 45 reference Raman spectra of minerals concerning research in art history or archaeology, especially on corroded metals and coloured glass. Spectrochimica Acta Part A. 2003:59:2247-66.

33. cf. electronic database RUFF from University of Arizona: http://rruff.info/ pre_rendered_graphs/raman_553_5062_9874_9875.png

34. Beresford-Jones D, Arce ST, Whaley OQ, Chepstow-Lusty A. The role of Prosopis in ecological and landscape change in the Samaca basin, lower Ica valley, south coast Peru from the early Horizon to the late Intermediate Period. Lat Am Antiq. 2009;2(20):303-32.

35. Sadesky A, Muckenhuber H, Grothe H, Niessner R, Pöschl U. Raman microspectroscopy of soot and related carbonaceous materials: Spectral analysis and structural information. Carbon. 2005;43:1731-42.

36. Beyssac O, Goffé B, Petitet JP, Froigneux E, Moreau M, Rouzaud JN. On the characterization of disordered and heterogeneous carbonaceous materials by Raman spectroscopy. Spectrochimica Acta Part A. 2003;59(10):2267-76.

37. Vaughn K, Linares Grados M, Eerkens JW, Edwards MJ. Hematite mining in the ancient Americas: mina Primavera, A 2,000 years old Peruvian Mine. JOM. 2007;59:16-20.

38. Eerkens JW, Vaughn K, Linares Grados M, Edwards MJ, La Ballena: a mining base camp in the Southern Nasca region, Peru. Antiquity, 2008, 82.

39. Montoya M, Caldas Vidal J, Garcia Marquez W, Carta geológico nacional [del Perú], Hojas 30-I, 30-m, 30-n, 30-ñ, Geología de los cuadrángulos de Lomitas, Palpa, Nasca y Puquio. Lima: INGEMMET, 1994.

40. Klohn Crippen B LTD, Evaluación ambiental territorial, Grupo de cuencas de la Costa Sur: Palpa - Nasca - Marcona, Acarí - Ocoña y Cerro Verde 
- Yarabamba - Puquina, Ministerio de Energía y Minas del Perú, Dirección General de Asuntos Ambientales, 1998.

41. Phipps E, Cahuachi Textiles in the W.D. Strong Collection: Cultural Transition in the Nasca valley, Peru. PhD: Columbia University, 1989.

42. Eerkens JW, Vaughn K, Linares GM. Pre-Inca mining in the Southern Nasca Region, Peru. Antiquity. 2009;83:738-50.

43. Bonavia D. Una pintura mural de Pañamarca, valle de Nepeña. Arqueológicas. 1959;5:48-9.

44. Eerkens JM, Barfod GH, Vaughn K, William R, Lesher C. Iron isotope analyses of red and black pigments on pottery in Nasca, Peru. Archaeol Anthropol Sci. 2014;6:241-54.

45. Vaughn K, Conlee C, Neff H, Schreiber K. A compositional analysis of Nasca pigments : implications for craft production on the Prehispanic
South Coast of Peru. In: Speakman RJ, Neff H, editors. Laser Ablation ICPMS: a new frontier in Archaeological characterisation Studies. Albuquerque: University of New Mexico Press; 2005. p. 139-54.

46. Kriss D, Howe E, Levinson J, Rizzo A, Caro F, DeLeonardis L. A material and technical study of Paracas painted ceramics. Antiquity. 2018;92:1492-510.

\section{Publisher's Note}

Springer Nature remains neutral with regard to jurisdictional claims in published maps and institutional affiliations.

\section{Submit your manuscript to a SpringerOpen ${ }^{\circ}$ journal and benefit from:}

- Convenient online submission

- Rigorous peer review

- Open access: articles freely available online

- High visibility within the field

- Retaining the copyright to your article

Submit your next manuscript at $\boldsymbol{\nabla}$ springeropen.com 